\title{
ANALYSIS ON SMALL SPACES WITH SPECIAL BEHAVIOR: STUDY CASE STUDENT HOUSING AT KOST PVKTF IN GADING SERPONG, TANGERANG
}

\author{
Sally Malinda ${ }^{1}$, Oktavianus Nangoy ${ }^{2}$ and Greysia Susilo ${ }^{3}$ \\ ${ }^{1}$ Bachelor student of Interior Design, Institut Sains dan Teknologi Pradita, Scientia Business Park, Banten, Indonesia \\ Email: Sally.malinda@student.pradita.ac.id \\ ${ }^{2}$ Lecturer of Interior Design, Institut Sains dan Teknologi Pradita, Scientia Bussiness Park, Banten, Indonesia \\ Email: oktavianus.nangoy@pradita.ac.id \\ ${ }^{3}$ Lecturer of Interior Design, Institut Sains dan Teknologi Pradita, Scientia Bussiness Park, Banten, Indonesia \\ Email: greysia.susilo@pradita.ac.id
}

Masuk : 16-04-2020, revisi: 30-04-2020, diterima untuk diterbitkan : 30-04-2020

\begin{abstract}
Student housing is a rent room used mainly for temporary living used by out-of-town students or commuting single workers. There are plenty of problem found in these long temporary living, basically the hard adjustment between their original room and facilities in their home, with standard and scarce facilities offered in the rent room. This research is study case based on one student housing room occupied by 2 persons and more than 10 reptiles and arachnoids. As a qualitative research, researchers gather data by keen observation and deep interview. After that researchers proposed several solutions as simple as changing resident's behavior, until redesign the rooms.
\end{abstract}

Keywords: small space, personal space, kamar kost, one room living

\begin{abstract}
ABSTRAK
Tempat kost adalah kamar sewaan yang digunakan terutama untuk tempat tinggal sementara yang digunakan oleh siswa dari luar kota atau pekerja lajang yang sering bepergian. Ada banyak masalah yang ditemukan pada tempat tinggal sementara ini, yang pada dasarnya adalah sulitnya penyesuaian antara kamar dan fasilitas di rumah mereka, dengan fasilitas dasar dan terbatas yang ditawarkan di kamar sewaan. Penelitian ini merupakan studi kasus berdasarkan satu ruang kost siswa yang ditempati oleh 2 orang dan lebih dari 10 reptil dan laba-laba. Sebagai penelitian kualitatif, peneliti mengumpulkan data dengan observasi secara teliti dan wawancara mendalam. Setelah itu, peneliti mengusulkan beberapa solusi mulai dari mengubah perilaku penghuni, hingga mendesain ulang ruangan.
\end{abstract}

Kata Kunci: ruang kecil, ruang pribadi, kamar kost, tempat tinggal satu ruangan

\section{INTRODUCTION}

Student rent room is a middle or long term living space. Indonesian term of student housing is kamar kost, literary means student room. In this research, the term student housing was limited to a single room, not the whole series of rooms in one building specially for students. Single room rent for student in Indonesia also demanded by young worker that work far from their original home.

According to UNESCO there are raising demand globally for student housing and single room rent around the world (Kiiskinen, 2016). The decision to pursue further study or better workplace send students and workers far from their original place, and commuting was less better option. Finding the convenient place was one challenging task to deal with, besides juggling living budget - food, stationary, books, tuition fees, health needs, and entertainment. Student housing was higher demand in bigger cities, where more and better education institution set up.

Student housing in Indonesia protected by government law. There are several government permit to comply for student housing to be built. Several that important are Building License (Izin Membangun Bangunan / IMB), Land Use License (Izin Pemanfaatan Tanah/IPT), Operational Housing Permit (Izin Operasional). The most special is Peraturan Pemerintah No. 34 Tahun 2017 
about Land and/or Building Rental License, with Student Housing Tax Income in article 2 clause 3.

There are several types of student housing, separated by its facilities, size, and furnishing. Their cost calculated by the existence of free wireless fidelity (wifi), common kitchen, private or common bathroom, and other facilities. Student housing also fall on several size type; usually separated by how many person it serves. There are one person single unit, two person single unit, and multiple person single unit - commonly named dormitory. Based on furniture existence, there are fully furnished student housing, half furnished ones, and empty unit. All those arrangements affect to the monthly cost they have to pay.

Tangerang was old city near Jakarta that developed first as satellite city, now begin to sort itself to be full independent city. Many business and commercial district developed and moved from Jakarta, but the sector that grow faster is education institutions. According to Badan Pusat Statistik (BPS, 2017), there are 113 private universities in 2013-2014, and now in more recent infographic, there are 118 universities based on 2019 PPDIKTI registration (https://forlap.ristekdikti.go.id/files/info grafis). According to Merdeka.com (Situmorang, 2017) Jakarta's urban problem, such as crowding, raising land cost, flooding, and decreasing housing space, all contribute to education place shift to Jakarta' satellite cities.

Gading Serpong, one masterpiece of PT. Summarecon Agung, cover around 1500 hectare area and contain 19 education institutions. Four of them are higher level education: Universitas Multimedia Nusantara, Matana University, Akademi Perawat Andalusia, and Pradita Institute. There are many student housing units were built. PT. Summarecon Agung even built two special clusters to accommodate student housing: Allogio Cluster and UMN dormitories. Beside the ones managed by developer, there are other student housings privately managed and built.

One of privately built student housing belong to Cluster Newton. One of the tenant rent $2.4 \mathrm{~m} \mathrm{x}$ $2.3 \mathrm{~m}$ room for two brothers. In the room only fit and devoted to single person, double occupancy create some problem. Aside its size, their behaviour led by young ages and lack of manage experience, unique hobby, made the problem worse. Many furniture there were used not by their common functions.

This research was to examine interior problem raised by occupants' mismanagement and misbehaviour until research team found alternative suggestions and solutions. It aims to minimize gap between ideal living space; its occupants' behaviour, activities, and needs; and limit created by space and budget.

The research using qualitative methods and using mainly critical observation and deep interviews for data collection (Kumar, 2011). Its analysis based on interior design private space analysis discussed in Karla Nielson's book (Nielson, 2006).

\section{THEORIES}

Before doing field research, theoretical data was gathered to enhance findings, support field data, and help to analyse the findings. Theoretical data begun with basic theory of one studio living interior design, basic temporary living interior, until special consideration for living space with many pets. 


\section{One Room Living}

Asia contains many top crowded cities in the world. The very high population made big impacts on their urban living; they getting smaller and compact each decade, Hongkong has cage room, New York has compact living competition and adult tree house. Tokyo develop tiny bathroom amenities, and around the world there are trend in convertible furniture (The Guardian, 2014).

\section{Middle - Long Temporary Housing}

Middle until long temporary housing have special considerations. Some of its aspects were shared with the hotel room standard interior arrangement. There always bedroom space, working / eating space, sitting space, storage space, and bathroom. On some lower type of hostel, the bathroom is excluded into common share bathroom outside private room. To comply with the length of stay, usually people will need cooking / food making space, since it will reduce cost of eating out each time. If it cannot included in the private room, then there will be common kitchen included as developer facility.

According to SINTEF case study in Thøgersen (Thøgersen, 2017) there are several missing qualities in small apartments: too small entrance space, too little storage space, no place for kitchen or pantry, no separate bedroom and no handicapped accessibility. On the other side, the positive factor of small student housing unit, it can be as near as the working or studying place as possible, only required communal buses or even walking distance. It usually squeezed out in shophouse blocks, even residential clusters. They are less resource to build or repaired from previous purpose, and less cost to maintain.

\section{Living Space with Pets}

Living space is basic need of every human being; it also has to accommodate their needs and wants - one of them is preference to have pets at home. One of the common preference of human is to live with some pets. Pets are adopted for many reasons. There are pets for play and fun, since some of them are considered cute or brawny - like dogs, cats. Some chosen because their extra functions, such as guarding or guiding for handicapped. Pets are considered in three viewpoints: as property, as companions, and as family. Those three viewpoints will determine the critical decisions the owner will made in emergency situation (O’Driscoll, ND).

Recently there is trend to treat pets into more companion and family viewpoints (O'Driscoll, ND). They are willing to spend more money on their pets, though it seems growing in vertebrates animals. Small creatures in invertebrates kingdom, such as Mollusca, Arthropoda, or Echinodermata still generally considered as property.

Letting pets coming into human's live will affect utilization of living space. There are countries that made regulations on minimum space requirement for pets, especially for mammals (US, UK, Canada), and even maximum quantity per household (Australia).

\section{Insects as Pets}

Citing www.keepinginsects.com, there are lots of people taking care and breeding insects to help them develop knowledge by observing their behaviour. Insects enthusiast love their unique and strange beauty, shape, colours, their strange habits, and even their lifecycles. Insects and some reptilian do not take much space to live, and their food mostly inexpensive (Linda, ND). The requirement space for insects are different according to their species, aside of that the rest requirements are general: escape proof, well ventilated, humid, correct temperature, and safe. 


\section{Reptiles as Pets}

Reptiles are sometimes classified as exotic pets. They are supposed to be wild, but held in captivity. Keeping them as pet will be challenging since they have specific environmental, dietary, and behavioural needs. According to Royal Society for the Prevention of Cruelty to Animals (RSPCA), there are growing numbers of reptiles as pets, with six popular species such as: bearded dragon, crested gecko, leopard gecko, corn snake, royal phyton, and Hermann's tortoise.

In Indonesia, keeping reptiles as pets like gecko almost always begun from fad attempt (www.agromedia.net), until they realize they love it or they want to get money from it as investment. These sometimes dangerous or poisonous creature has be to well maintained.

\section{Universal and Multifunction Furniture}

Furniture is basic human necessities, spreading out around their living space. According to Eckleman in Thøgersen (Thøgersen, 2017) "people sits on it, sleep on it, eats on it, and perhaps most importantly, puts his most valuable belongings into it".

Convertible furniture is one solutions offered by Dwell on Design, it varies from desks and sofas convert into beds, drawers pulled from under stairs, storage space pushed up to vertical until ceilings. Elevated bedroom as extra layer will leave no space left underutilized (The Guardian, 2014). These multifunctional furniture will reduced their normal $50 \%$ occupation on floor space.

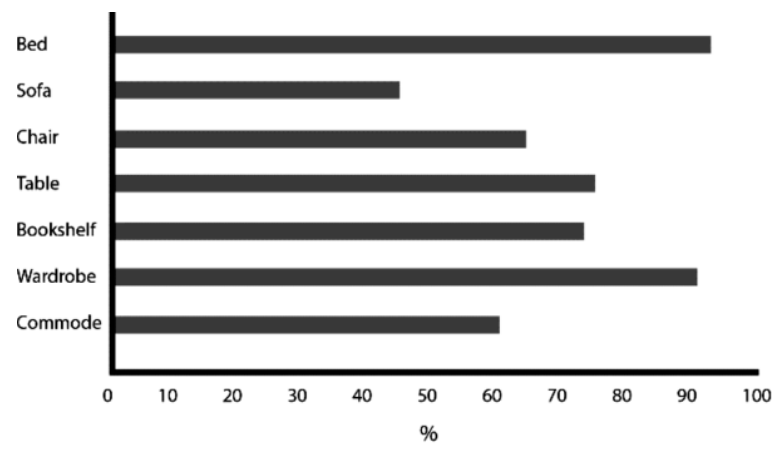

Figure 1: Main Furniture in a small apartment (Source : Thøgersen, 2017)

Figure 1 represents order of furniture that is most common in one bedroom apartments. Bed and wardrobe as the most needed, commode and sofa are the ones will missing quickly when the space is lessen. The next problem arise according to Thøgersen (Thøgersen, 2017) is the increasing size of furniture in recent decade. People getting taller each generations and they are not used to tiny small furniture to occupy their needs.

There are some recent development to meet solutions for saving spaces. Thøgersen proposed multifunctional furniture, modular furniture and transformable furniture. Multifunctional furniture is furniture that can perform more than one function, while modular furniture is furniture that divided into parts and sold separately to accommodate the size and function needed. The ideas came mainly from office modular furniture of 70's. Transformable furniture was believed based on traditional murphy bed, and Japanese washitsu - multipurpose typical room.

\section{Human Behavior}


People have their limitation on how small they can bear to live. Byggteknisk forskrift and Johansen finding in Thøgersen (Thøgersen, ND) said that minimum size for one bedroom living space is $7-10 \mathrm{~m}^{2}$. This arrangement will grow crowded feeling; a psychological feeling of too small space and can lead to claustrophobic disease.

McMains on Thøgersen claims that when environment is cluttered, there will be growing chance to lost concentration and focus in residents (Thøgersen, 2017). It will disturb brain's ability to process information, big problem when the residents are mostly students and active workers that also bring work to home. When there are more than one resident stay in the same room, the problem increase into relationship problem - growing apart, violence, and abuse (Urist, 2013).

One of interior solutions based on the changing of the occupant's behaviour is to develop habit of tidying up. This means to put things always in order, according to its functions or the occupant's needs. Things that spread out and scattered around the room will make mess; after sometimes it will develop dust and dirt, and will affect to health. Stalling and delaying in sorting out things will decrease the cleanliness and enhance feeling of cramped and crowdedness.

The newest trend in art of tidying up space belong to Marie Kondo (Pratiwi, 2017). She is a Japanese women that introduce KonMari theory, the bold action of sorting out and maintain consistency. Her main principle is spark of joy when we touch our belongings. When the feeling is right, then next come the clustering things, start from clothes, books, papers, then memorable stuff.

\section{STUDY CASE BACKGROUND}

In this section, researchers present the field research study of the unit. It begin with the basic information of student housing unit researched, then examination by observation, and completed by interview points.

\section{Student Housing Unit (Kost)}

Indonesian student housing unit (kost) is medium until long temporary living space that rent for certain period of time and usually paid in monthly basis. There are several government regulations to obey. First, license to build (Izin Mendirikan Bangunan / IMB) is issued by local government to protect housing owner in buying and selling properties. Second, Housing owner need to have License of Land Use (Izin Pemanfaatan Tanah / IPT) if the owner plan to build more than 10 unit in the housing. This will change land designation from private into commercial land use.

\section{Kost Pvkt}

The study case in this research is a student housing units in Gading Serpong area, inside Newton Shophouse blocks, named Kost Pvktf, Jl. NB. It contains 17 units in four story shophouses building. The ground floor is not used for housing units; instead they create professional cafe for public use. The facilities inside Kost Pvktf are wifi, hot water, full furniture, and laundry service. There are also caretaker who always clean the common areas regularly, and clean resident's room for extras.

There are several regulations to follow:

1. Any kind of pets are not allowed.

2. Guests are allowed until 22.00 PM.

3. Outside guests are forbidden to stay overnight. 
4. Rent payment maximum 3 (three) days before end of rent term, and paid to caretaker or bank transfer.

5. Resident should give one month advance notice if want to end rent term. Deposit money will be given back after damage examination.

6. Maintain cleanliness and taking care housing facilities as their own.

7. Owner or caretaker is not responsible for the lost items inside rent unit.

8. Gambling, drinking, bring alcohol and drugs are not allowed.

9. It is mandatory to compensate for lost or damage rent inventory inside the unit or at housing facilities.

10. Making trouble and loud noise is forbidden.

11. Using wifi beside private use is forbidden.

\section{The Tenant}

The tenant are two young men that are brothers. Since there is no consent given to reveal their names, the older one will be called Mr. A and the younger one Mr. G. The older brother Mr.A is currently student at Universitas Multimedia Nusantara, fourth semester, 20 years old. Mr. G is student at Pradita Institute second semester, 19 years old.

They original home is at Cengkareng area, Jakarta Barat - around 30km from Gading Serpong. Their parents decided to rent student housing for them to save energy, time, and money for commuting; instead they investing on renting monthly around 1.9 mill rupiah. They started to rent unit in Kost Pvktf together since November 2018. Before they rent room in residential cluster in the same area Kost Pvktf proved to be cheaper and clean.

Mr. A has passion for exotic creature since small boy, but the parents forbid him to acquire them. When the boys move out from their parents' house, Mr. A see opportunity to start getting the pets. It started around December 2018 with one tarantula spider named Don, then he doubled it to become 15 tarantulas until now. Beside that, there are 3 scorpions acquire at January 2019 and one big gecko around $20 \mathrm{~cm}$ length. One time he even buy snake but decide to let it go again after one week. Aside primary animals, there are also Madagascar cockroaches tended as the food for tarantula and geckos.

All creatures are pets, since some of them are named; they also a form of investments, since they are valuable to trade when they are bigger.

\section{The Unit}

The room is in third floor, with 2 rows of units in each side, divided by single corridor. The room is $2.4 \mathrm{~m} \times 2.2 \mathrm{~m}$, and intended to use by single person.

\section{Layout}

Kost Pvktf has a modern approach on its interior arrangement. Instead of laying its furniture flat on the floor, it create overhang layer in form of double size bunk bed floating $2.2 \mathrm{~m}$ from floor. In empty unit, the room looks spacious and adequate to single person living.

The bed is accessible by narrow stairs which also serve as shelf storage. The bunk bed with stairs is special made unit that attached permanently to the room.

The most exceptional furniture exist in this unit is the portable quarter shower box, which convenient to use and does not occupy much space. This solution was offered by owner to maintain competing facilities with lack of space in regular shophouses. 


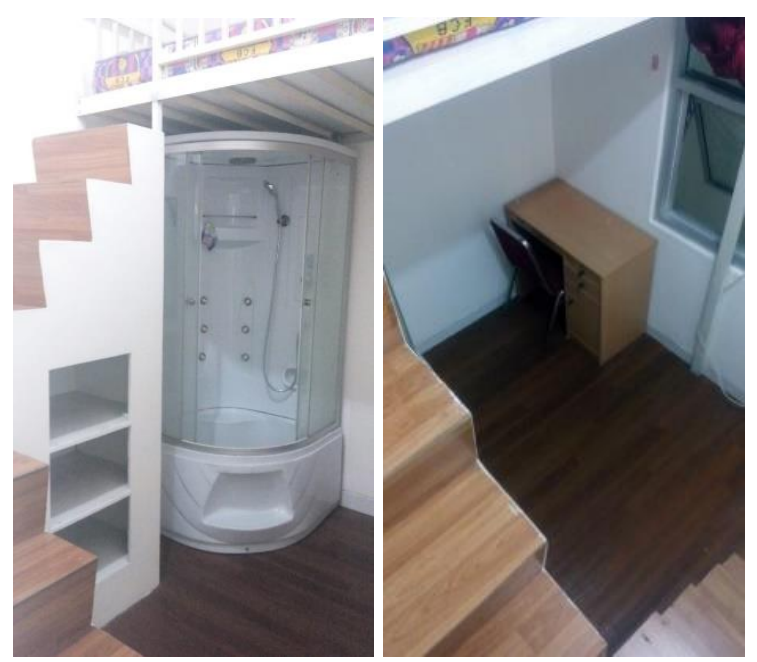

Figure 2: Empty unit: underneath bed - shower box and study table (Source: Sally, 2019)

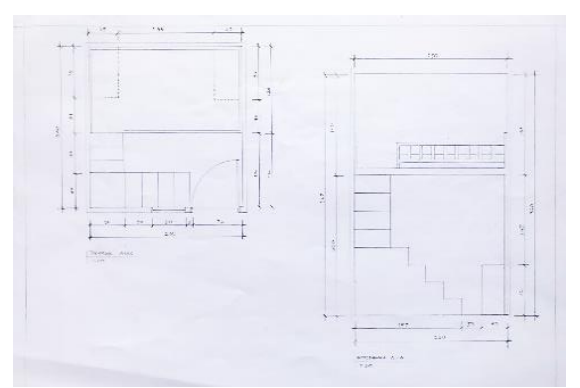

Figure 3: Layout and A-A’ Section of Unit (Source: Sally, 2019)

The layout and sections tell us that the room is quite spacious for single person, and have high ceilings. The most private area will be on the top, while daily activities concentrated at floor level.

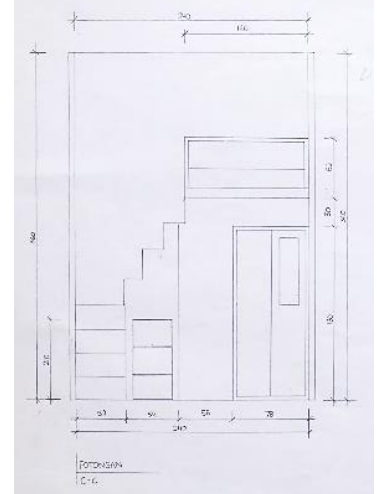

Figure 4: C-C' Section of Unit (Source: Sally, 2019)

\section{Observation}

As the two young men are fresh out from their parents' house, it is natural to expect their difficulties in adjusting to live independently. The lack of experience was shown from the pictures below. 


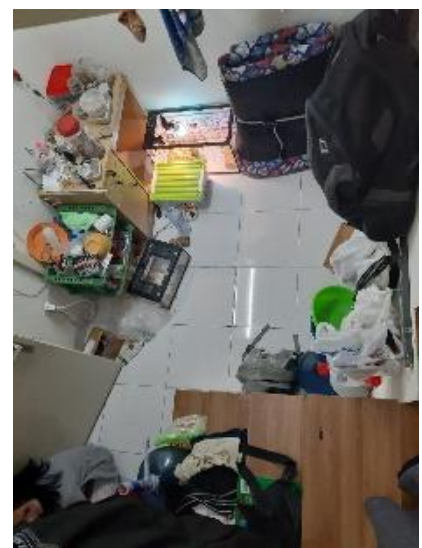

Figure 5: Real condition of the unit 1 (Source: Sally, 2019)

In figure 5 there are a lot of mess going on at floor level. They take out the portable shower box out and insert portable floor bed that can be rolled when not in use. Top right corner, the study table was full of insects and reptiles cages, unable to use for their original function. A lot of plastics just laying on the top of each other, reducing space and increasing feeling crowdedness.

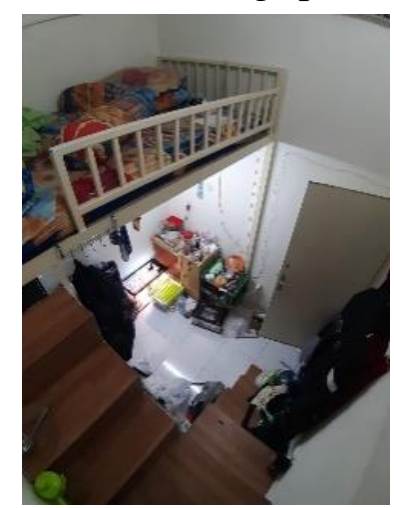

Figure 6: Real condition of the unit 2 (Source : Sally, 2019)

In Figure 6 the bed is shown enough for one adult or at least 2 teenagers, so the brothers decided to sleep in separate place. Mr. A the older got privilege to stay on top, while Mr. G the younger got the rolled bed underneath. Beside the door and hanging at the bottom of the bed, there are several hooks to hang things. Most are occupied with their clothes and some plastic bag or paper bags. There are things also overload to occupy the narrow stairs, make it hard to step up. 
Figure 7: Real condition of the Unit 3 (Source: Sally, 2019)

In Figure 7 we see clearly other side underneath bed. There is standard 2 doors wardrobe with additional shelves beside it. All full and stacked with stuff, and more plastic bags shown. Underneath plastics bags, there is one golden bottle that looks like cooking oil. It seems, from time to time the brothers cooked simple food at common kitchen area outside.

\section{Interview}

The interview held in one class session of ID 101 Teori Dasar Interior in Pradita Institute, by all researchers at Monday, March 10, 2019. It start from basic information about the two brothers, and how they ended up in Kost Pvktf. Next round the interview goes to facilities, their behavior, and everyday routine around the room. Next step is to investigate arrangement of the insects and reptiles.

There are unique facts that Mr. G told to researchers about their lives with 20+ animals:

- All the animals belongs to Mr. A, but Mr. G help to tend them regularly.

- Some animals need sunbathing regularly, and the brothers took turn to take them outside.

- Mr. G have love and hate relationships with the animals, similar feeling to his brother. He hates to stay with them, but he also develop growing fondness for the creatures.

- Mr. G is helpless in this situation. He feels the crowd and feeling cramped inside his own unit. Most of the time he spent his daily activities outside his room, and only came to sleep.

- Mr. G scarcely using his room for eating, studying, or relaxing. The place is mainly for sleeping and storage area.

- Their parents at first against ideas to cramp their housing unit with those animals, but since Mr. A can convince them that the creatures have some value in trade and trend, they agree on minimum level.

- The parents came to visit them at weekends, and Mr. G admit that their mother will spent most of her time inside the unit to clean up and sorting out the mess.

\section{ANALYSIS}

In this section, researchers analyse findings and arrived into four steps suggestion to make better interior in the Unit. The suggestions steps are arranged according to the budget they need to apply it. The first, suggestion is discussed around the tenant's behaviour that need change. For this suggestion, there will be minimum budget spent - since the correction is gathered around the behaviour. The second step is to rearrange furniture; the cost is less but the option also very limited. The third step is to change some furniture. There are several variation in this step: add, remove, or change. The budget also varies and higher. The fourth step is to complete redesign. This is a major renovation that require certain budget to comply.

Before analysis, researchers discuss the ideal room for 2 person. The output are bubble diagram, and activities - facilities tables. 


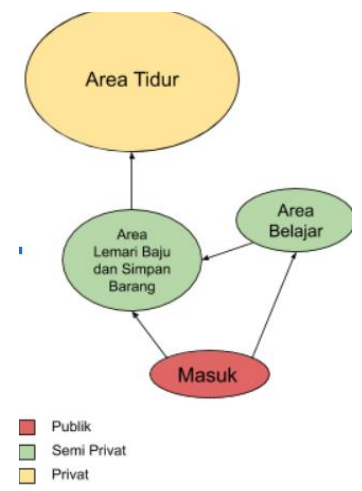

Figure 8: Bubble diagram for standard student housing unit (Source : Sally, 2019)

After developing the activities and facilities tables, conclusions is made that minimum requirement housing unit for 2 person is not less than $11 \mathrm{~m}^{2}$. The space are enough for double bed, small dining table with 2 chairs, study table with chair, double storage for miscellaneous stuff and wardrobe.

\section{Behaviour Assessment}

The lack of experience in living independent almost always shows at freshmen. They still adjusting in new environment in their university, they also has to adjust in living solo. The ignorance of keeping thing strict and straight also contribute to the mess, while the wave of new friends tend to make them busy made connections and forget to tend their 'new nest'.

KonMari is one solution to sorting out the mess. As the theory said above, it will help the brothers to sorting out. The limit for their stuff is the closed space inside shelf or wardrobe. They have to develop rules not to put things outside of its storage space. If there is no more space to put new things, they have to decide which stuff that goes out and replace with the new stuff they need.

Although KonMari seems to be good solution to govern better cleanliness behaviour, individuality also big considerations. Each person have their preferences and activities; so the furniture and layout of the room has to accommodate their different needs and wellbeing. At this case, parents, or even the brothers have to calculate the fitness of the room. If the emotional burden will have deep impact in long term, then they always have to figure way out. Booking separate cheaper rooms for the brothers maybe beneficial to better health and emotional state, and maybe cheaper than buying sophisticated modern furniture that can fit to small space.

\section{Rearranging Furniture}

The next alternative solution is rearranging furniture. In this scheme, there are no basic furniture were taken out or new ones getting in. The discussions finds two steps to accomplish.

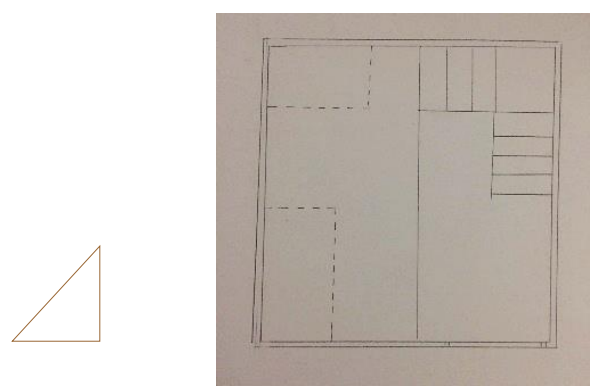

Figure 9: Layout after rearranging furniture (Source : Sally, 2019) 
Based on Figure 9, first is to change bed position, vertical to the door. It pair with the changing position of the stairs, facing doors, rather than horizontal to door. The changing will make the bed longer from $2.2 \mathrm{~m}$ into $2.4 \mathrm{~m}$. It means there will be chance to put more shelf at the head or foot of the bed, with $20 \mathrm{~cm}$ width.

This arrangement have benefit of more storage space to put at the foot or head of the bed, and clearer view from door, to get slightest open feeling and reduce crowdedness.

\section{Changing Some Furniture}

The next discussion examine the potential furniture to add or take out. Since the standard room is given by owner as part of the rent cost, those furniture can not moved out, except the shower box. Those furniture are basic essential furniture that still in active functions.

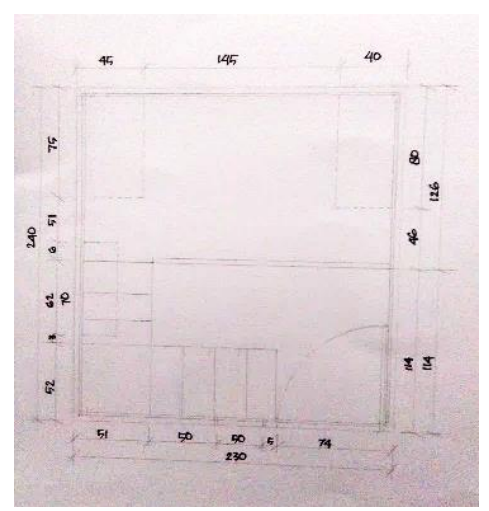

Figure 10: Layout after adding Furniture (Source : Sally, 2019)

Adding furniture is one alternative solution. Discussion proposed wall shelf for storing terrarium or jars of pet reptiles and insects. It can placed along the door wall beautifully, as part of wall decoration.

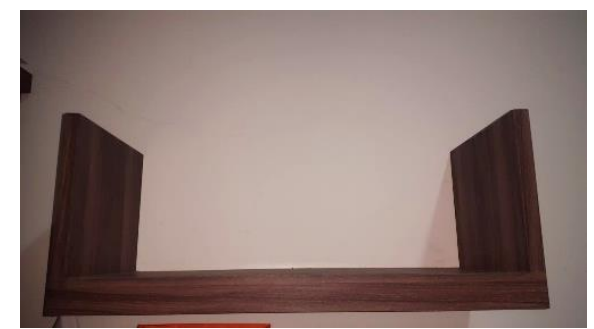

Figure 11: Wall Shelf for the pets (Source : Sally, 2019)

\section{Redesign}

Below are the proposed discussion if redesign can be applied to the unit. 


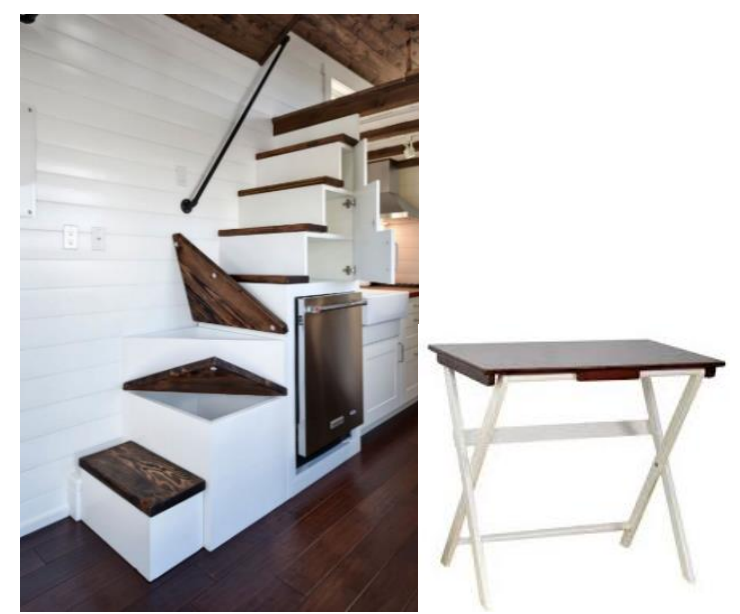

Figure 12. Redesign ideas for the unit

1. Multifunction furniture that enhance flexibility and furniture that can hide stuff will add empty space and enhance feeling of not crowding.

2. Changing colors into bright ones and adding some mirror to doubled the feeling of space. This classical way will make small room feel roomy and larger.

3. Change the window facing outdoor if possible. The smell of outdoor will reduce crowding feeling and enhance air circulation.

4. Vertical storage and wall shelves.

5. Vertical straight stairs.

6. Horizontal lines with its optical illusion will stretch out the feeling of roomy and larger space.

7. Furniture that can be folded and stored by hanging it at the wall or stacking it.

\section{CONCLUSION}

Environment can change behaviour of the residents; like otherwise. In this research, changing behaviour is attest from the behaviour assessment. It is difficult path, but will sort any interior environment problem. If we cannot change the behaviour of the residents, then the only solutions left is to change the interior environment. Rearranging furniture, changing furniture, and complete redesign will be considered as prime ready solution.

\section{ACKNOWLEDGEMENTS}

This research is done as major assignment at DI 101 Theory of Interior Design course, second semester, in Interior Design Department, Pradita Institute. This group study contains 12 members: Silvyana Thio, Priska Veriyanti, Veila Venisa, Nathya Puspa Arum, Korina Katriana, Sally Malinda, Afifa Karamina Awanys, Gerardo Harisson Setianto, Ribka Paulin, Ariella Clariesta Audrey, Mikhael Immanuel Kelana, and Siti Inayah. Sally Malinda is the chief researcher.

All except Figure 1, and Figure 12, are self made images, copyright belong to researchers.

Figure 12 copyright: https://godiygo.com/2018/ 10/22/49-cool-tiny-house-design-ideas-toinspire-you/cool-tiny-house-design-ideas-to-inspire-you-38/ and https://www.blibli.com/p/livienfrench-country-meja-belajar-lipat/pc--MTA-2548693?ds=LIF-39163-00304-

00001\&source=SEARCH_OR_CATEGORY_PAGE

\section{REFERENCES}

AgroMedia. (ND). Cara tepat memilih dan merawat reptil dan amfibi kesayangan. 
https://agromedia.net/cara-tepat-memilih-dan-merawat-reptil-dan-amfibi-kesayangan-2/

Badan Pusat Statistik, (2017). Jumlah perguruan tinggi, mahasiswa, dan tenaga edukatif (negeri dan swasta) di bawah kementrian pendidikan dan kebudayaan menurut provinsi tahun ajaran

2013/2014-2014/2015. https://www.bps.go.id/statictable/2015/09/14/1839/jumlah-perguruan-tinggimahasiswa-dan-tenaga-edukatif-negeri-dan-swasta-di-bawah-kementrian-pendidikandan-kebudayaan-menurut-provinsi-2013-2014-2014-2015.html

Kiiskinen, A. T. L. V. (2016). A design concept proposal about compact living units: Use case for student housing. Limnaeus University. http://www.divaportal.org/smash/get/diva2:1038538/FULLTEXT01.pdf

Kumar, R. (2011). Research methodology: Step-by-step guide for beginner. Los Angeles: Sage Publication

Linda. (ND). Why keep bugs? https://www.keepinginsects.com/introduction/why-keep-bugs/

Nielson, K. J., Taylor, D. A. (2006). Interiors: An introduction $\left(4^{\text {th }}\right.$ ed). Mc.Graw-Hill Education.

O'Driscoll, A. (ND). The role of a pet. http://www.pets.ca/dogs/articles/the-role-of-a-pet/

Pratiwi, Y. (2017, November 13). Metode beberes rumah dari Jepang konmari dari marie kondo. TEMPO.CO. https://www.google.com/amp/s/cantik .tempo.co/amp/1033160/metodebeberes-rumah-dari-jepang-konmari-dari-marie-kondo

RSPCA. (2017). Understanding the motivations of beginner reptile owners. https://www.rspca.org.uk/webContent/staticImages/Downloads/ReptileReport.pdf

Situmorang, A. P. (2017, January 30). Jakarta diminta fokus pada sektor jasa, industri pindah ke bekasi. Merdeka.com. https://www.merdeka.com/uang/jakarta-diminta-fokus-padasektor-jasa-industri-pindah-ke-bekasi.html

The Guardian. (2014). Are tiny houses and micro-apartments the future of urban living? Trapped in Hong Kong. https://www.theguardian. com/sustainable-business/014/aug/25/tiny-housesmicro-living-urban-cities-population-newyork-hongkong-tokyo

Thøgersen, K. (2017). Small spaces need smart solutions designing furniture for small spaces, in connection with human wellbeing. https://www.ntnu.edu/documents/139799/1279149990/31+Article+Final_krithog_fors\%C3 \%B8k_2017-12-07-22-08-50_TPD4505+-+Designteori++Small+spaces+need+smart+solutions+-+Kristoffer+Th\%C3\%B8gersen.pdf/11a2f430986b-4da8-9b44-14b204436e01

Urist J. (2013, December 19). The health risks of small apartments. The Atlantic. https://www.theatlantic.com/health/archive/2013/12/the-health-risks-of-small apartments/282150/ 